\title{
Geology Along Topographic Profile for Near-Surface Test Facility
}

K. R. Fecht

\section{January 1978}

Prepared for the United States

Department of Energy

Under Contract EY-77-C-06-1030

\section{Rockwell International}

Rockwell Hanford Operations

Energy Systems Group

Richland, WA 99352 


\section{DISCLAIMER}

This report was prepared as an account of work sponsored by an agency of the United States Government. Neither the United States Government nor any agency Thereof, nor any of their employees, makes any warranty, express or implied, or assumes any legal liability or responsibility for the accuracy, completeness, or usefulness of any information, apparatus, product, or process disclosed, or represents that its use would not infringe privately owned rights. Reference herein to any specific commercial product, process, or service by trade name, trademark, manufacturer, or otherwise does not necessarily constitute or imply its endorsement, recommendation, or favoring by the United States Government or any agency thereof. The views and opinions of authors expressed herein do not necessarily state or reflect those of the United States Government or any agency thereof. 


\section{DISCLAIMER}

Portions of this document may be illegible in electronic image products. Images are produced from the best available original document. 


\title{
Q
}

\section{Rockwell International}

Rockwell Hanford Operations

Energy Systems Group

Richland, WA 99352

\author{
PREPARED FOR THE UNITED STATES DEPARTMENT OF ENERGY \\ UNDER CONTRACT EY-77-C-06-1030
}

\section{PRELIMINARY REPORT}

This Report contains information of a preliminary nature. It is subject to revision or correction and therefore does not represent a final Report. It was prepared primarily for internal use within The Rockwell Hanford Operations. Any expressed views and opinions are those of the Author and not necessarily of the Company.

\section{NOTICE}

This Report was prepared as an account of work sponsored by the United States Government. Neither the United States nor the United States Department of Energy, nor any of their Employees, nor any of their Contractors, Subcontractors, or their Employees, makes any warranty, express or implied, or assumes any legal liability or responsibility for the accuracy, completeness, or usefulness of any information, apparatus, product or process disclosed, or represents that its use would not infringe privately owned rights. 


\title{
GEOLOGY ALONG TOPOGRAPHIC PROFILE FOR \\ NEAR-SURFACE TEST FACILITY
}

K. R. Fecht

Earth Sciences Group Research Department

\section{for \\ Basalt Waste Isolation Program}

NOTICE

This report was prepared as an account of work sponsored by the United States Government. Neither the Ented States not he United States Department of Energs, nor any of their employees, nor any of their contors, subcontractors, or their employees, makes any warranty, express or imptied, of assumes any legal habily or responsibility for the accuracy, completeness or usefulress of any information, apparatus, product or process disclosed, or represents that its use would no infringe privately owned rights.

\author{
Basalt Waste Isolation'Program
}

January 1978 


\section{A B S T R A C T}

The U. S. Department of Energy, through the Basalt Waste Isolation Progran within Rockwell Hanford Operations, is investigating the feasibility of terminal storage of radioactive waste in deep caverns constructed in the Columbia River Basalt. This report represents a portion of the geological work conducted in support of the Engineering Design Unit to evaluate the west end of Gable Morntain as a site for in situ testing of the thermomechanical behavior of basalt.

The surficial geology of the west end of Gable Mountain was mapped in a reconnaissance fasinion at a scale of 1:62,500 to identify geologic features which could affect siting of the proposed facilities. A detailed study of the geological condilivuls was conducted along a traverse across the most probable site for the proposed project. 
TABLE OF CONTENTS

$\begin{array}{lr}\text { INTRODUCTION } & \frac{\text { Page }}{4} \\ \text { PREVIOUS STUDIES } & 4 \\ \text { METHODS OF INVESTIGATION } & 4 \\ \text { TOPOGRAPHY } & 6 \\ \text { STRATIGRAPHY } & 6 \\ \text { GEOLOGIC STRUCTURE } & \cdots \\ \text { ATTITUDE OF STRATA } & 10 \\ \text { FRACTURING DUE TO DEFORMATION } & 10 \\ \text { FAULTING } & 13 \\ \text { PRIMARY STRUCTURES } & 13 \\ \text { ACKNOWLEDGMENTS } & 17 \\ \text { REFERENCES } & 17 \\ \text { DISTRIBUTION } & 17\end{array}$

LIST OF FIGURES

FIGURE 1 LOCATION OF GABLE MOUNTAIN STUDY AREA

FIGURE 2 FLOW IDENTIFICATION 7

$\begin{array}{llll}\text { FIGURE } & 3 & \text { BASALT STRATIGRAPHY EXPOSED ON GABLE MOUNTAIN } & 8\end{array}$

FIGURE 4 WESTERN END OF GABLE MOUNTAIN 9

$\begin{array}{llll}\text { FIGURE } 5 \text { UPPER TERTIARY STRATIGRAPHY OF GABLE. MOUNTAIN } & 11\end{array}$

$\begin{array}{llll}\text { FIGURE } & 6 & \text { STRATIGRAPHY IN WELL DB-9 } & 12\end{array}$

$\begin{array}{llll}\text { FIGURE } & 7 & \text { GENERALIZED GEOLOGIC CROSS SECTION, } & \\ & & \text { WESTERN. END OF GABLE MOUNTAIN }\end{array}$

$\begin{array}{llll}\text { FIGURE } & 8 & \text { MAJOR INTRAFLOW STRUCTURES } & 16\end{array}$

$\begin{array}{llll}\text { FIGURE } & 9 & \text { ANOMALOUS ZONES IN POMONA FLOW, } \\ \text { SOUTHERN GABLE MOUNTAIN ESCARPMENT } & 18\end{array}$

\section{LIST OF PLATES}

PLATE 1 TOPOGRAPHIC PROFILE FOR PROPOSED NEAR-SURFACE TEST FACILITY SITE 


\section{INTRODUCTION}

The purpose of this study was to conduct geologic investigations on the west end of Gable Mountain as part of the Near-Surface Test Facility siting studies at Hanford. The location of the study area is shown in Figure 1.

This geologic work was conducted by the Earth Sciences Group of the Research Department at the request of the Engineering Design Unit of the Basalt Waste Isolation Program. It is within the general scope of the fiscal year 1978 geologic work being conducted on Gable Mountain by the Earth Sciences Group for the Geosciences Unit of the Basalt Waste Isolation Program, but provides added detail that was requested by the Engineering Design Unit for information needed in evaluating various Near-Surface Test Facility sites on Gable Mountain.

The geologic investigations were conducted on December 12, 1977 and consisted of two tasks. Task 1 was a detailed study of the geologic conditions along a traverse across the most probable site for the proposed Near-Surface Test Facility project. Task 2 was a geologic reconnaissance of the west end of Gable Mountain to identify geolngic. features which could affect siting of the proposed facilities. The results of both tasks are presented in this report.

\section{PREVIOUS STUDIES}

Since the startup of the Hanford operations, the Gable Mountain-Gable Butte area has been examined as part of numerous hydrologic, geologic, and geophysical studies. (1-12) Three of these studies $(7,10,11)$ were concerned specifically with the structure and stratigraphy of the Gable Mountain-Gable Butte area. Their observations and interpretations were incorporated into this study.

\section{METHODS OF INVESTIGATION}

Bașalt Waste Isolation Program personnel surveyed an approximate north-south traverse across the west end of Gable Mountain with a theodolite and determined elevations along the traverse at horizontal intervals of 100 feet. This provided vertical control during geologic mapping. 


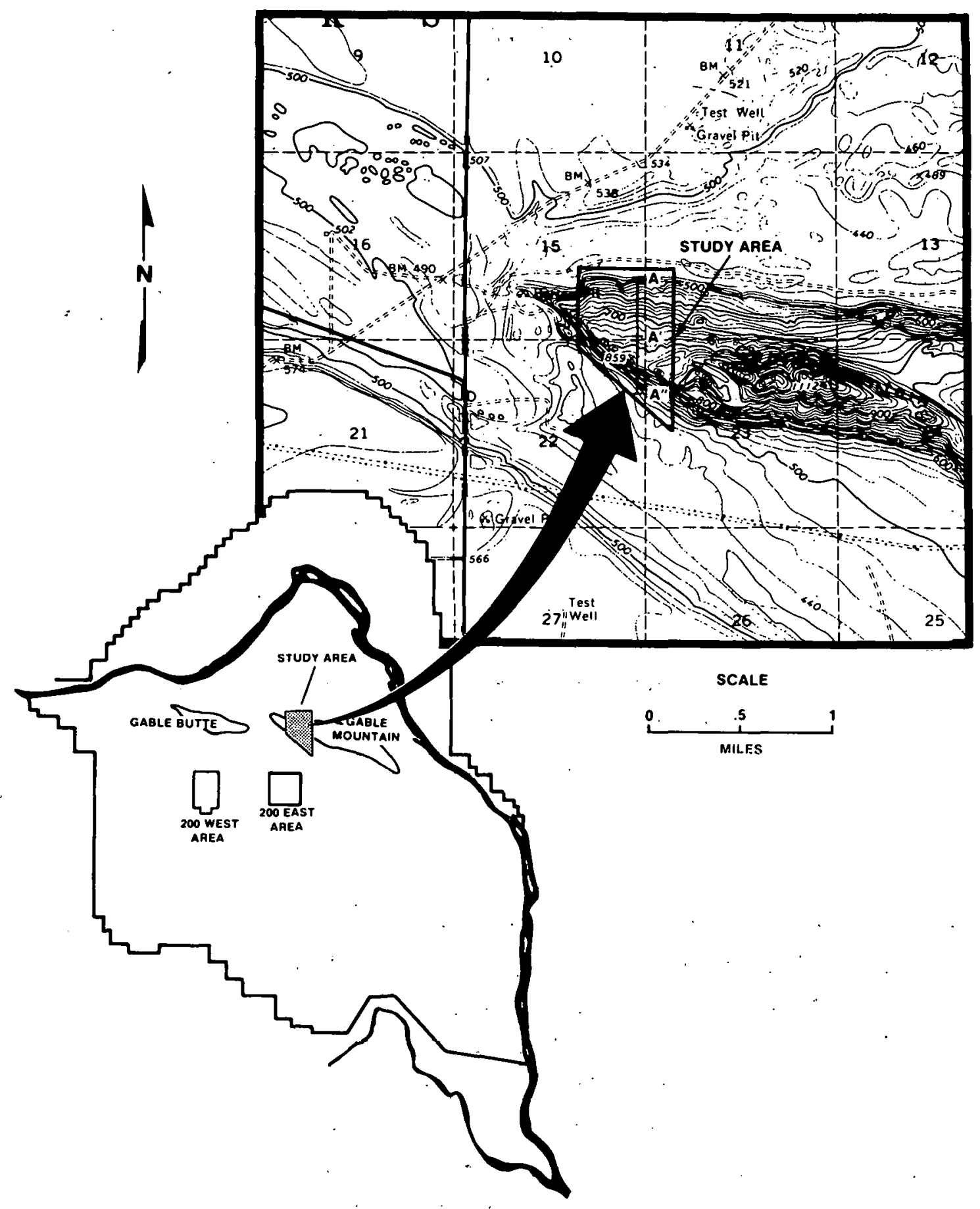

FIGURE 1

LOCATION OF GABLE MOUNTAIN STUDY AREA 
Detailed mapping along the traverse consisted of: (1) hand-specimen examination of basalt outcrop for petrographic characteristics and post-solidification deformation; (2) description of exposed geologic units and potential zones of deformation not related to cooling or deposition; and, (3) correlation of the geologic units and intraflow structures present.

Geologic measurements between traverse stations and on the south face of Gable Mountain (Plate 1, Stations $-6+00$ to $0+00$ ) were made with a tape and Brunton compass. Geologic observations, measurements, and other, data were recorded in a field notebook.

Seven basalt samples were collected from four flows and analyzed for $\mathrm{CaO}$ and $\mathrm{TiO}_{2}$ chemical composition using Rockwell Hanford Operations' energy dispersive $X$-ray fluorescence unit. These seven samples were oriented before being collected in order to determine the natural remanent magnetic polarities using a flux gate magnetometer.

The chemical composition, natural: remanent magnetism, stratigraphic position, and hand-specimen petrography were used in basalt unit identification and correlation. The analytical data and stratigraphy are. given in Figures 2 and 3 . Sample localities are recorded on Plates 1 and 2.

\section{TOPOGRAPHY}

The south-facing cliff of basalt along the southern part of the study area (Plate 1., Stations $0+00$ to $-1+50$ ) is termed the "southern Gable Mountain escarpment" in this report. The base of this escarpment is covered by talus (Plate 1, Stations $-1+50$ to $-4+50$ ). Exposed in this escarpment are the Elephant Mountain flow, Rattlesnake Ridge Interbed, and the upper part of the Pomona flow. The Elephant Mountain flow also forms another small escarpment on the west and north ends of the study area. The scven to ten-dcgrec slope over most of the northern three-quarters of the study area (Plate 1, Stations $0+00$ to 22+00) is primarily a dip slope (see Figure 4) of the Elephant Mountain f.low.

\section{STRATIGRAPHY}

Exposed on the western end of Gable Mountain are four basalt flows of Saddle Mountains Basalt: Elephant Mountain; Pomona; Gable Mountain; and, 


\begin{tabular}{|c|c|c|c|c|c|c|}
\hline $\begin{array}{r}\text { (1) } \\
\text { SAMPLE NO. }\end{array}$ & $\begin{array}{r}\text { (2) } \\
\text { STRAT } \\
\text { POS. }\end{array}$ & $\begin{array}{l}\text { PETROGRAPHIC } \\
\text { CHARACTERISTICS }\end{array}$ & $\begin{array}{l}\text { BULK } \\
\text { CHEA } \\
\text { (v } \\
\text { CaO }\end{array}$ & $\begin{array}{l}\text { (4) } \\
\text { OCK } \\
\text { STRY } \\
\text { 10) } \\
\text { TIO22 }\end{array}$ & NRM $^{\text {N(5) }}$ & $\begin{array}{l}\text { FLOW } \\
\text { IDENTIFICATION }\end{array}$ \\
\hline $\mathbf{C} 6000$ & 1 & NEARLY APHYRIC & 7.2 & 3.2 & NORMAL & ELEPHANT MOUNTAIN \\
\hline C6001 & 1 & NEARLY APHYRIC & 7.2 & 2.5 & NORMAL & ELEPHANT MOUNTAIN \\
\hline C6002 & 1 & NEARLY APHYRIC & 7.6 & 2.4 & NORMAL & ELEPHANT MOUNTAIN \\
\hline $\mathrm{C6003}$ & 1 & NEARLY APHYRIC & 7.6 & 2.2 & NORMAL & ELEPHANT MOUNTAIN \\
\hline C6005 & 2 & ABUNDANT OLIVINE & 8.8 & 1.2 & REVERSED & POMONA \\
\hline C6006 & 4 & DIABASIC TEXTURE & 9.6 & 1.2 & NORMAL & HUNT ZINGER \\
\hline C6007 & 3 & PHYRIC & 6.4 & 2.2 & NORMAL & GABLE MOUNTAIN \\
\hline
\end{tabular}

(1) Sample localities are given on Plates 1 and 2 .

(2) Stratigraphic sequence from youngest flow (1) to oldest flow (4).

(3) See Plate 2.

(4) Determined using energy dispersive $X$-ray fluorescence unit.

(5) Natural remanent magnetic polarity determined using flux gate magnetometer.

(6) See Figure 3.

FIGURE 2

FLOW IDENTIFICATION 


\begin{tabular}{|c|c|c|c|}
\hline FECHT (1978) & WPPSS (1974) & BROOKS (1974) & $\begin{array}{c}\text { BINGHAM et al } \\
(1970)\end{array}$ \\
\hline $\begin{array}{l}\text { ELEPHANT } \\
\text { MOUNTAIN }\end{array}$ & $\begin{array}{l}\text { ELEPHANT } \\
\text { MOUNTAIN }\end{array}$ & $\begin{array}{l}\text { ELEPHANT } \\
\text { MOUNTAIN }\end{array}$ & $\begin{array}{l}\text { ELEPHANT } \\
\text { MOUNTAIN }\end{array}$ \\
\hline POMONA & POMONA & POMONA & POMONA \\
\hline $\begin{array}{l}\text { ESQUATZEL } \\
\text { (GABLE } \\
\text { MOUNTAIN) }\end{array}$ & PRIEST RAPIDS & $\begin{array}{l}\text { UNCORRELATED } \\
\text { CHEMITYPE } 2\end{array}$ & PRIEST RAPIDS 4 \\
\hline $\begin{array}{c}\text { ASOTIN } \\
\text { (HUNTZINGER) }\end{array}$ & & $\begin{array}{l}\text { UNCORRELATED } \\
\text { CHEMITYPE } 1\end{array}$ & PRIEST RAPIDS 3 \\
\hline
\end{tabular}

FIGURE 3

BASALT STRATIGRAPHY EXPOSED ON GABLE MOUNTAIN 


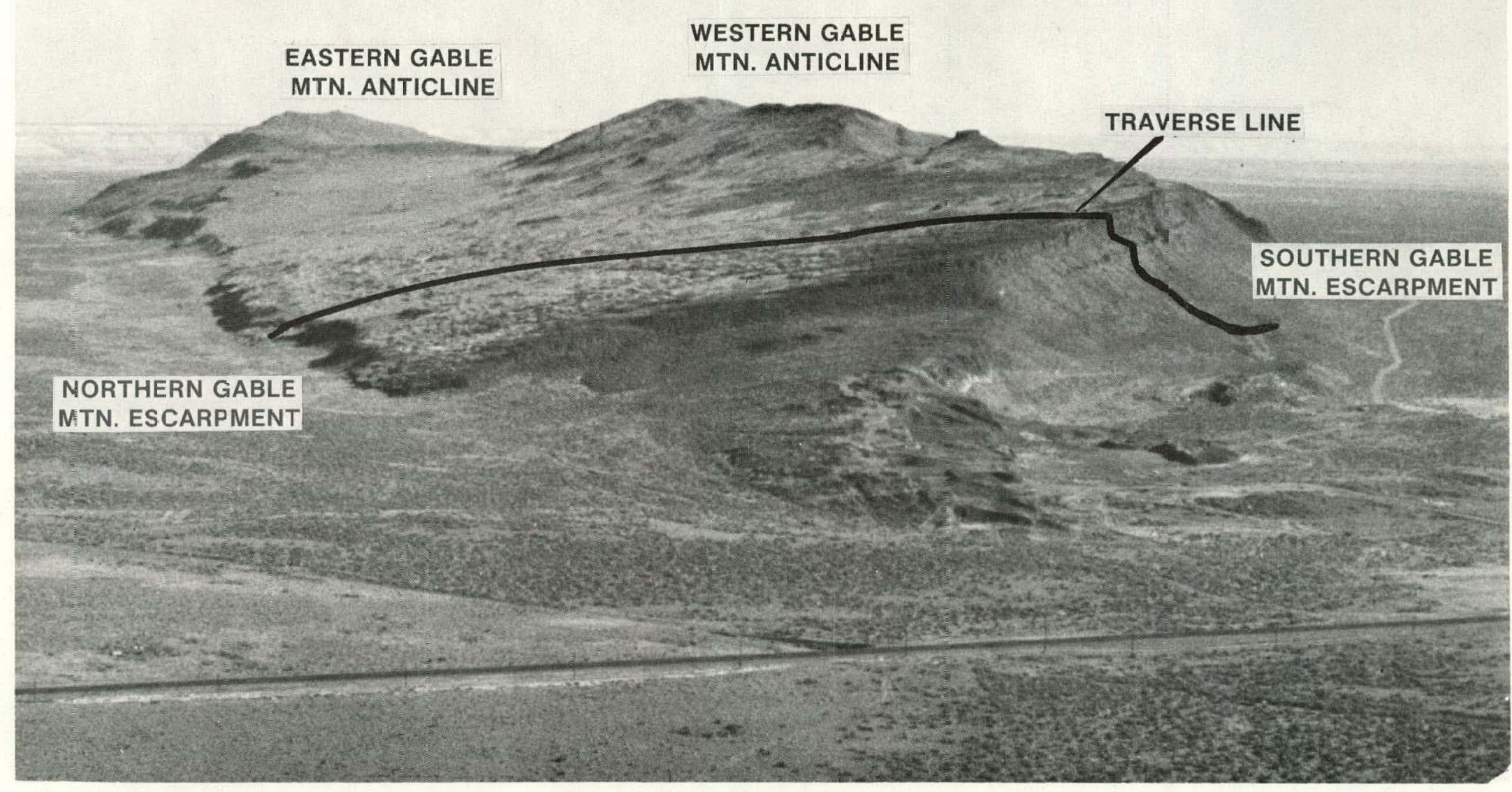

FIGURE 4

WESTERN END OF GABLE MOUNTAIN 
Huntzinger, youngest to oldest, respectively (Figure 5). Intercalated between the basalt flows are two sedimentary interbeds of the Ellensburg Formation. The upper sedimentary unit is Rattlesnake Ridge, which is situated between the Elephant Mountain and Pomona flows and is exposed on the southern Gable Mountain escarpment. Core from We11 DB-9, located on the west end of Gable Mountain, reveals the lower sedimentary unit, the Selah Interbed, between the Pomona and Gable Mountain flows (Figure 6); the Selah is not exposed at the surface in the study area.

The Tertiary basalt flows and interbedded El lensburg sediments are overlain by Quaternary sedimentary units. These Quaternary units include glaciofluvial sands and gravels, eolian silts and fine sands, basalt rubble, talus, and landslide debris.

Descriptions of the geologic units present on the western end of Gable Mountain and a geologic map showing their distribution are given on Plate 2.

\section{GEOLOGIC STRUCTURE}

Because this study was conducted to assist the Basalt Waste Isolation Program in their siting studies for the Near-Surface Test Facility project, investigations of specific types of geologic structures were emphasized. These included: (1) attitude of strata; (?) fracturing due to deformation; (3) faulting; and, (4) primary structures.

\section{ATTITUDE OF STRATA}

The basalt flows and interbed exposed along the traverse dip seven to ten degrees to the north (Figure 4). These geologic units are on the gently dipping north $1 \mathrm{imb}$ of an asymmetric fold, the western Gable Mountain anticline. The south limb of the western Gable Mountain anticline is exposed east of the study area. Within the study area, the south limb and crestal portion of the anticline were apparently stripped away by the catastrophic floods from glacial Lake Missoula producing the southern Gable Mountain escarpment.

At the northern limit of the study area (Plate 1, Stations $22+00$ to $25+00$ ), the dip of the Elephant Mountain flow steepens, as evidenced by an approximate 32-degree north dip (Plate 2), east of the study area. The 


\begin{tabular}{|c|c|c|}
\hline $\begin{array}{l}\text { ELEPHANT MTN. } \\
\text { MEMBER (Tsem) }\end{array}$ & ELEPHANT MTN. FLOW & \\
\hline$\cdot$ & & RATTLESNAKE RIDGE (Ter) \\
\hline POMONA MEMBER(Tspo) & POMONA FLOW & \\
\hline & & SELAH (Tes) \\
\hline $\begin{array}{l}\text { ESQUATZEL } \\
\text { MEMBER (Tse) }\end{array}$ & GABLE MTN. FLOW & \multirow{2}{*}{$\ldots$} \\
\hline $\begin{array}{c}\text { ASOTIN } \\
\text { MEMBER (Tsh) }\end{array}$ & HUNT ZINGER FLOW & \\
\hline
\end{tabular}

FIGURE 5

UPPER TERTIARY STRATIGRAPHY OF GABLE MOUNTAIN 


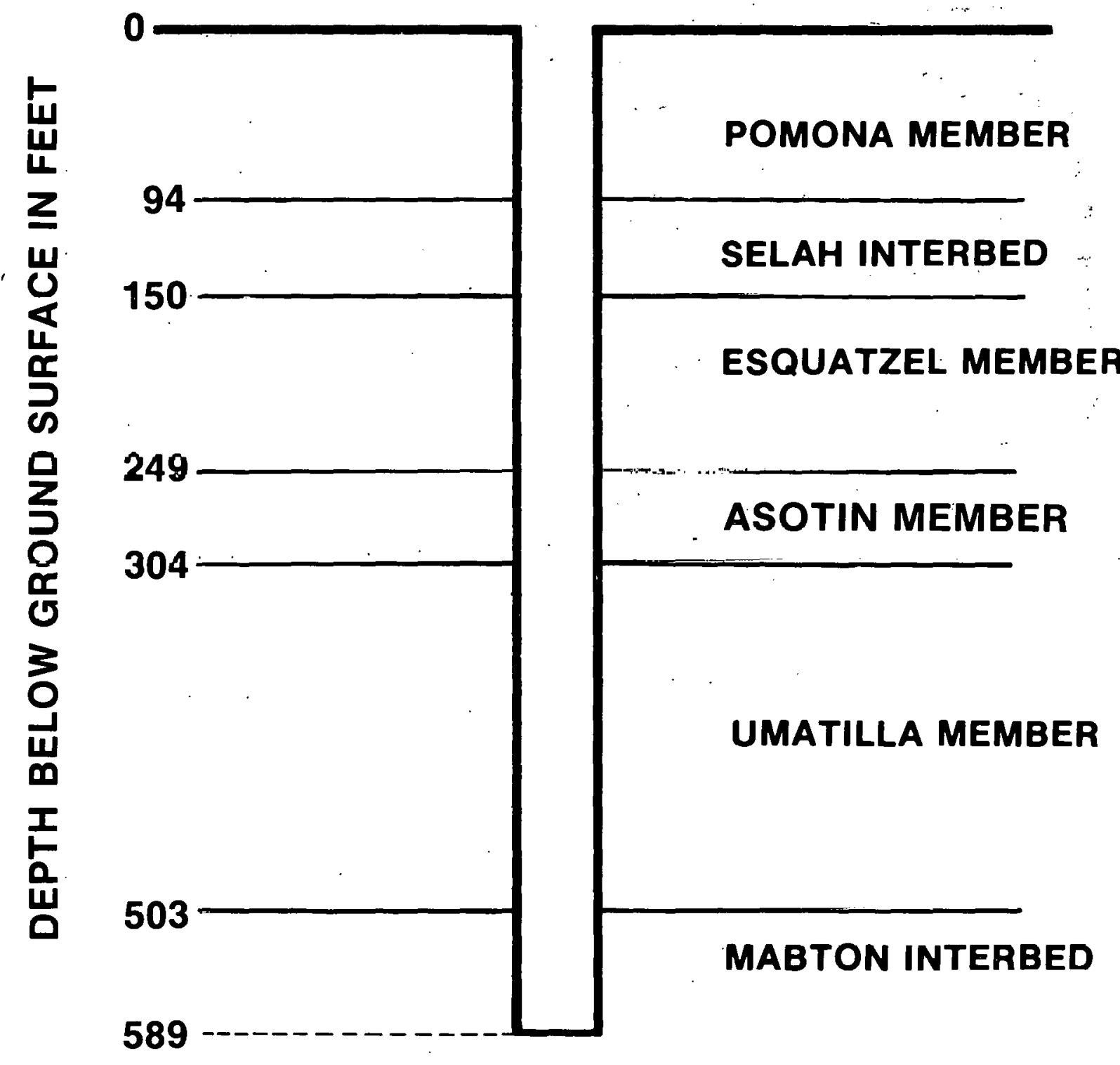

FIGURE 6

STRATIGRAPHY IN WELL DB-9 
Missoula glacial flood waters have also stripped the basalt from the northern edge of Gable Mountain forming a 20-foot escarpment (Figure 7).

FRACTURING DUE TO DEFORMATION

Between Stations $-2+00$ and $22+00$ (Plate 1), the ubiquitous fractures in the basalt flows are primary structures related to the cooling history of the flows. Here, no evidence for shearing, brecciation, displacement, or other deformation was found other than that which would be produced during cooling. Post-solidification deformation would, however, be expected along the east-west-trending anticlinal axis of the western Gable Mountain anticline that is projectd south of Station $-6+00$ (Plate 1) outside of the study area. As stated above, this portion of the anticlinal axis was eroded and then covered during the Missoula glacial floods. Such deformation can be observed about one mile east of the study area.

A second flexure and area of post-solidification fracturing is inferred immediately north of Station 22+00 (Plate 1), based upon the apparent steepening of the Elephant Mountain flow observed east of Station 24+00 (Plate 2). Although this flexure is on the very northern limit of the study area, the inferred post-solidification fracturing could impact on the Near-Surface Test Facility site located near the northern limit of the study area.

FAULTING

The geologic units were examined for evidence of faulting. Field criteria used for the identification of possible faults were: (1) shearing; (2) brecciation; (3) displacement; or, (4) linear escarpments. Examination of the geologic units revealed no evidence of shearing, brecciation, or displacement in the study area. One prominent linear escarpment, the southern Gable Mountain escarpment, is interpreted as an erosional escarpment (see "Attitude of. Strata"), but its tectonic significance is not known berause of the limited exposure. This study, as with the three previous studies, $(7,10,11$,$) revealed no evidence of$ exposed faults within the study area or evidence for projecting faults known from elsewhere in the Hanford vicinity into the study area. However, immediately east of the study area on the western Gable Mountain anticline is a northerly trending fault which is exposed on the southern Gable Mountain escarpment. Stratigraphic offset can be seen near the 
ridge crest where the Pomona flow is in juxtaposition with the Elephant Mountain flow with about 33 feet of vertical displacement. The fault plane, which is totally obscured by talus debris, is estimated to dip at 30 degrees to the east as suggested by Bingham, et al. (7) The stratigraphic relationships and dip of the fault plane indicate the fault to be a low-angle reverse fault with about 82 feet of offset. The trace of the fault over the northern flank of the western Gable Mountain anticline is discernible for only 130 to 165 feet beyond the crest before becoming obscured in the scabland topography and a veneer of eolian loess. No evidence of shearing or brecciation in basalt outcrops was noted north of where the fault is last exposed.

\section{PRIMARY STRUCTURES}

Close examination of primary structures in the study area was limited to the Pomona flow, because the entablature of this flow has been identified as the most likely zone for the Near-Surface Test Facility subsurface facilities. A typical flow from Columbia River Basalt has three primary structures: (1) flow top; (2) entablature; and, (3) colonnade (Figure 8). The Pomona flow in the study area has these typical primary structures plus one other, informally named anomalous zone in this report.

The Pomona flow is exposed only along the southern and western escarpments in the study area. Along these escarpments, the principal primary structures in the Pomona flow are: (1) the flow top; (2) the upper colonnade; (3) the entablature; and, (4) the lower colonnade. The flow top consists of a highly vesicular, glassy basalt grading downward into the more dense basalt of the upper colonnade. The upper colonnade consists of near-vertical, massive, long, undulating columns ( 1.5 to 3.0 feet in diameter) with many cross joints and large scattered vesicles. The upper colonnade grades abruptly downward into the entablature. The entablature consists of near-vertical; long, well-developed, slender columns ( 0.5 to 1.0 feet in diameter), but displays hackly jointing formed by the intersection of the ubiquitous vertical joints. and cross joints. The entablature appears to constitutc ncarly two-thirds of the Pomona flow in the study area. The contact between the entablature and 


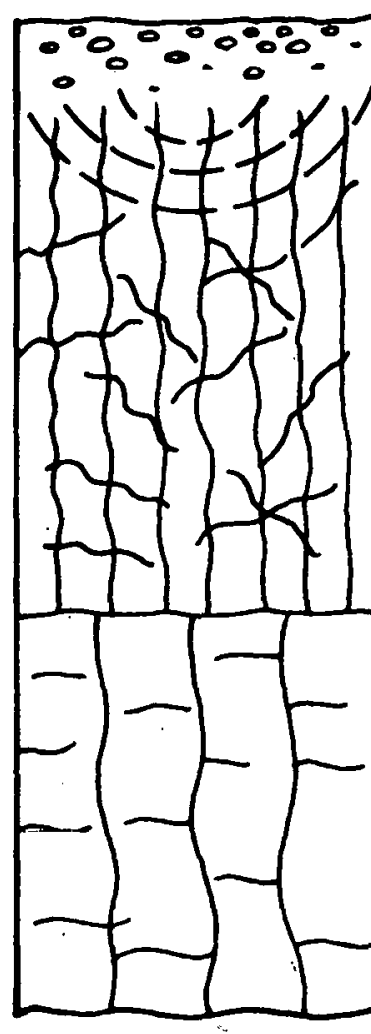

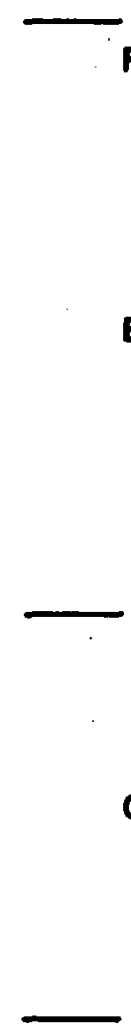

FLOW TOP

ENTABLATURE

COLONNADE

FIGURE 8

MAJOR INTRAFLOW STRUCTURES
VESICULAR, GLASSY, LOCALLY SCORIACEOUS

LONG SLENDER COLUMNS COMMONLY BROKEN INTO HACKLY FRAGMENTS UNDULATING COLUMNS

(After D. A. Swanson ${ }^{[12]}$ ) 
lower colonnade is poorly exposed. The lower colonnade, which comprises less than one-third of the Pomona flow, consists of near-vertical, large, blocky, well-developed columns (1.3 to 2.0 feet in diameter).

Two anomalous zones representing localized, abrupt changes in primary structure of the Pomona flow have been identified in the southern Gable Mountain escarpment (Figure 9). These anomalous zones are highly vesicular, rubbly portions of the flow top that extend downward into the upper colonnade. The upper part of the entablature beneath these anomalous zones consists of long, slender columns arranged in a fan-shaped pattern that stands in sharp contrast to the long, slender columns arranged in a near-vertical pattern elsewhere in the Pomona entablature. Although these anomalous zones appear to be local features, their northern extent closer to the proposed Near-Surface Test Facility site is not known. The proximity of these anomalous zones to the proposed Near-Surface Test Facility site is important because of their potential influence on the thermal and mechanical response of the Pomona basalt during operation of the facilities.

\section{ACKNOWLEDGMENTS}

Mr. S. D. Sharpe surveyed the traverse and determined the station elevations; Mr. R. K. Ledgerwood provided core well logs and helpful well log interpretations. Ms. M. G. Jones analyzed the basalt samples for $\mathrm{CaO}$ and $\mathrm{TiO}_{2}$ using the energy dispersive $X$-ray fluorescence unit. Special thanks goes to Dr. C. W. Myers for his many useful suggestions, comments, and reviews during the course of this work. Their assistance is most appreciated.

\section{REFERENCES}

1. D. H. Hart and F. J. Frank, "Aquifer Evaluation Test in the Gable Mountain Area," U. S. Geological Survey Open File Report, 1954.

2. J. R. Raymond, The Magnetic Method of Geophysical Exploration on the Hanford Project - Interim Report, HW-57309, General Electric Hanford Atomic Products Operation, RichTand, Washington, 1958. 


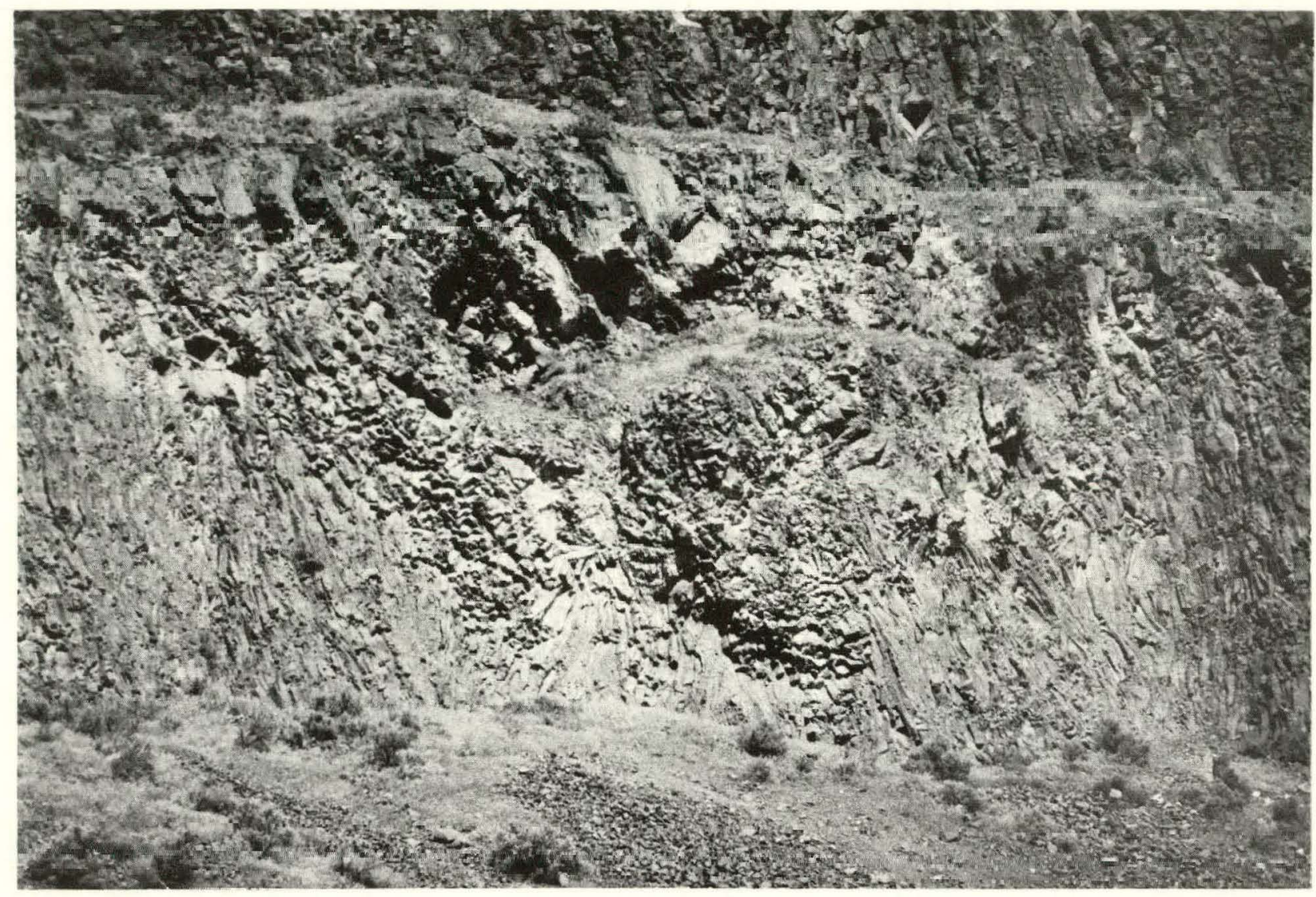

FIGURE 9

ANOMALOUS ZONES IN POMUNA HLUW, SOUTHERN GABLE MOUNTAIN ESCARPMENT 
3. J. R. Raymond and V. L. McGhan, Results of an Airborne Magnetometer Survey of the Hanford Project, HW-78924, General Electric Hanford Atomic Products Operation, Richland, Washington, 1963.

4. D. E. Peterson and R. E. Brown, Gravity Anomalies and Geologic Structures of the Central Part of the Columbia River Basalt Plateau, BNWL-SA-812, Battelle, Pacific Northwest Laboratories, Richland, Washington, 1966.

5. Logs of Exploration Trenches on Gable Mountain, at the Hanford Works of the U. S. Atomic Energy Commission, Richland, Washington, Converse, Davis and Associates, Pasadena, California, 1969.

6. R. D. Mudd, D. B. Clearlock, and A. E. Reisenauer, Analys is of Hydrological Factors Influencing the Gable Mountain Irrigation Project, BNWL-1502, Battelle, Pacific Northwest Laboratories, Richland, Washington, 1970.

7. J. W. Bingham, C. J. Londquist, and E. H. Baltz, "Geologic Investigations of Faulting in the Hanford Region," U. S. Geological Survey Open File Report, 1970.

8. Logs of Exploratory Trenches on Gable Mountain at the Hanford Works of the U. S. Atomic Energy Commission, Richland, Washington, Converse, Davis and Associates, Pasadena, California, 1971.

9. R. C. Newcomb, J. R. Strand, and F. J. Frank, "Geology and Ground-Water Characteristics of the Hanford Reservation of the U. S. Atomic Energy Commission, Washington," U. S. Geological Survey Professional Paper 717, 1972.

10. W. E. Brooks, Stratigraphy and Structures of the Columbia River Basalt in the Vicinity of Gable Mountain, Benton County, Washington, M. S. Thesis, University of Washington, Seattle, Washington, 1974.

11. Washington Public Power Supply System Preliminary Safety Analys is Report, WPPSS Nuclear Project No. 1, Richland, Washington, 1974

12. D. A. Swanson, "Yakima Basalt of the Tieton River Area, South-Central Washington," Geological Society of America Bulletin, $\underline{78}$,

pp. 1077-1110, 1967 .

DISTRIBUTION

Number of

Copies

1 s. F. T. AGAPITD

1 CENTRAL WASHINGTON UNIVERSITY

Department of Geology 
Distribution (continued)

Number of Copies

COLORADO SCHOOL OF MINES

1 J. W. CORWINE

1 GEOSCIENCE RESEARCH CONSULTANTS

J. G. Bond

IDAHO BUREAU OF MINES AND GEOLOGY

M. M. Miller

1

OREGON STATE DEPARTMENT OF GEOLOGY AND MINERAL INDUSTRIES

J. D. Beaul ieu

1

OREGON STATE UNIVERSITY

Department of Geology

1

PACIFIC NORTHWEST LABORATORY

J. R. Raymond

1 F. L. PARKER.

1 . I. REMSON

1 R. SCHNEIDER

1 G. SERVOS

1 U. S. ARMY-YAKIMA FIRING CENTER

W. R. Dietderich

1

U. 3. BUREAU OF. RECLAMATION

Columbia Basin Pro,fect Geologist

1

U. S. DEPARTMENT OF ENERGY-COLUMBUS PROGRAM OFFICE

J. Neff

2

U. S. DEPARTMENT OF ENERGY-HEADQUARTERS

M. W. Frei

D. L. Vieth

U. S. DEPARTMENT OF ENERGY-RICHLAND OPERATIONS OFFICE

R. B. Goranson

D. J. Squires (2)

1. U. S. GEOLOGICAL SURVEY-WATER RESOURCES DIVISION

C. Collier

1

U. S. GEOLOGICAL SURVEY-WESTERN DIVISION

D. A. Swanson

1

UNIVERSITY OF IDAHO

Department of Geology 
Distribution (continued)

Number of

Copies

1

1

1

1

1

1

1

1

1

46
UNIVERSITY OF OREGON

Department of Geology

UNI VERSITY OF WASHINGTON

Department of Geology

WASHINGTON PUBLIC POWER SUPPLY SYSTEM, INC.

D. D. Tillson

WASHINGTON STATE DEPARTMENT OF ECOLOGY

P. M. Grimstad

WASHINGTON STATE DEPARTMENT OF NATURAL RESOURCES

V. E. Livingston

WASHINGTON STATE UNIVERSITY

Department of Geology

A. C. WATERS

H. C. WEI SENECK

WESTERN WASHINGTON UNIVERSITY

Department of Geology

ROCKWELL HANFORD OPERATIONS

H. Babad

D. J. Brown

D. J. Cockeram

T. A. Curran (5)

R. A. Deju (2)

R. C. Edwards

K. R. Fecht (5)

R. E. Gephart

R. J. Gimera

R. E. Isaacson

A. D. Krug

C. W. Myers

W. H. Price (5)

M. J. Smith

Basalt Waste Isolation Program Library (15)

Document Control (4) 


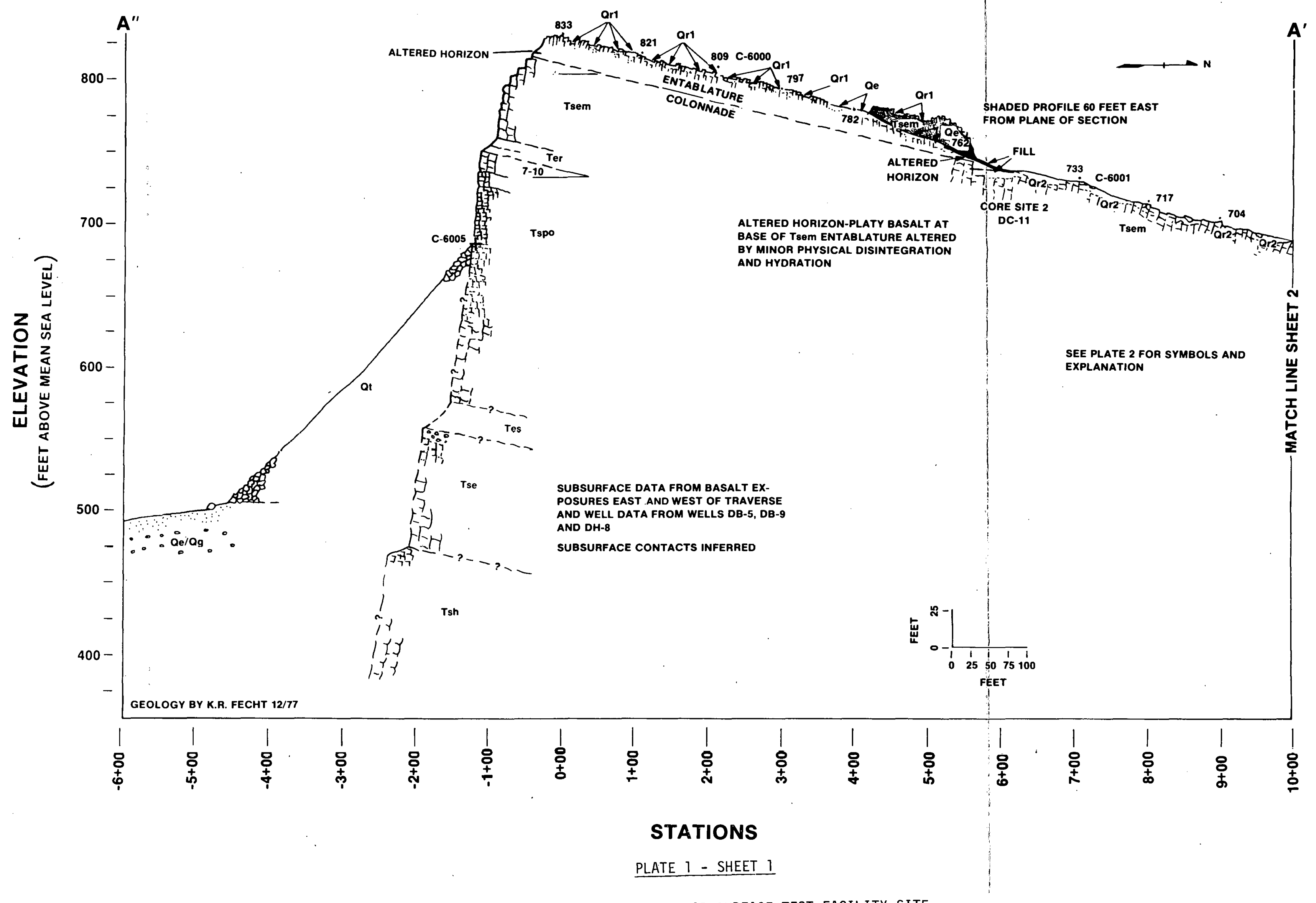

TOPOGRAPHIC PROFILE FOR PROPOSED NEAR-SURFACE TEST FACILITY SITE 


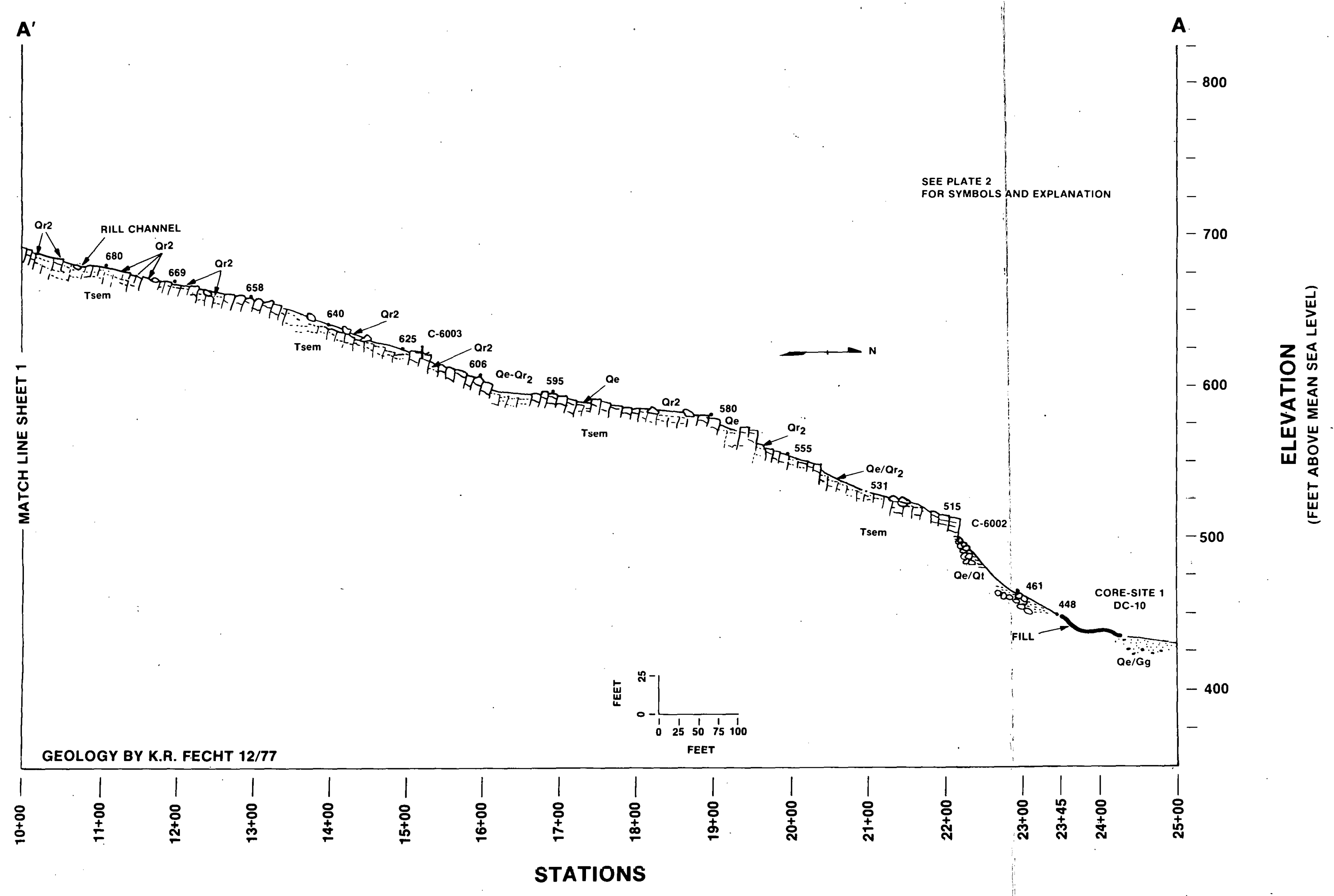

PLATE 1 - SHEET 2

TOPOGRAPHIC PROFILE FOR PROPOSED NEAR-SURFACE TEST FACILITY SITE 


\begin{tabular}{|c|c|c|}
\hline & $\begin{array}{c}\text { UNIT } \\
\text { SYMBOL: }\end{array}$ & $\begin{array}{c}\text { LEGEND } \\
\text { UNITS } \\
\end{array}$ \\
\hline & Qe & EOLIAN DEPOSITS \\
\hline & Qls & LANDSLIDE \\
\hline a & at & TALUS \\
\hline$\stackrel{\square}{\partial}$ & $\mathrm{or}_{1}$ & $\begin{array}{l}\text { RUBBLE-ELEPHANT } \\
\text { MOUNTAIN ENTABLATURE }\end{array}$ \\
\hline & $\mathrm{ar}_{2}$ & $\begin{array}{l}\text { RUBBLE-ELEPHANT } \\
\text { MOUNTAIN COLLONNADE }\end{array}$ \\
\hline & Qg & GLACIOFLUVIAL DEPOSITS \\
\hline & Tsem & ELEPHANT MOUNTAIN \\
\hline & Ter & RATTLESNAKE RIDGE \\
\hline & Tspo & POMONA \\
\hline & Tes & SELAH \\
\hline & Tse & $\begin{array}{l}\text { ESQUATZEL } \\
\text { (GABLE MOUNTAIN) }\end{array}$ \\
\hline & Tsh & $\begin{array}{l}\text { ASOTIN } \\
\text { (HUNTZINGER) }\end{array}$ \\
\hline
\end{tabular}

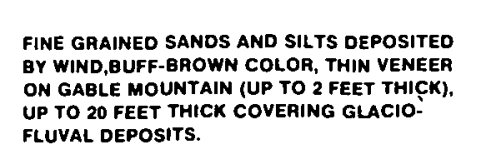

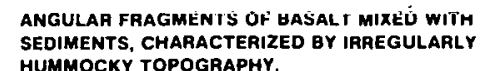

ANGULAR FRAGMENTS OF MASS WASTTE BASAL
AT THE AASE OF CLIFS.

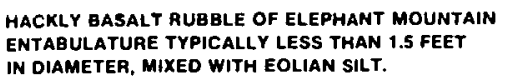

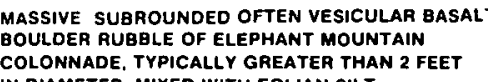

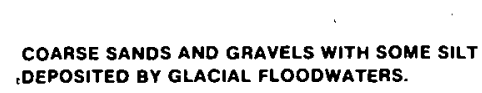
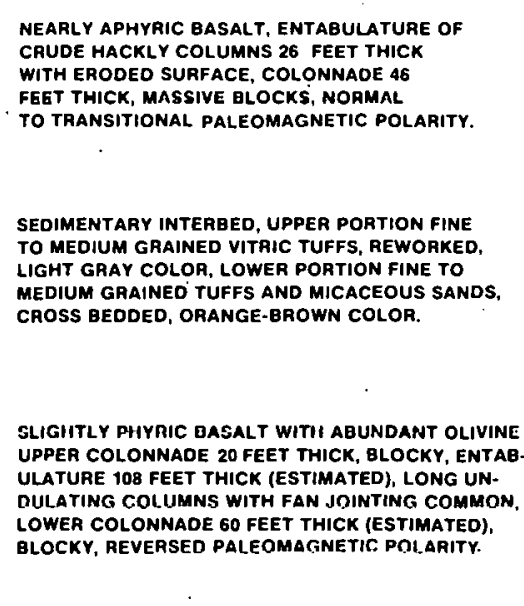

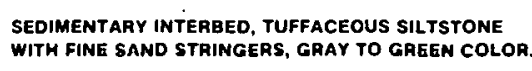

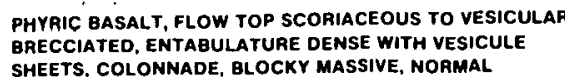

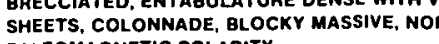

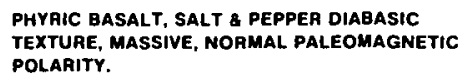

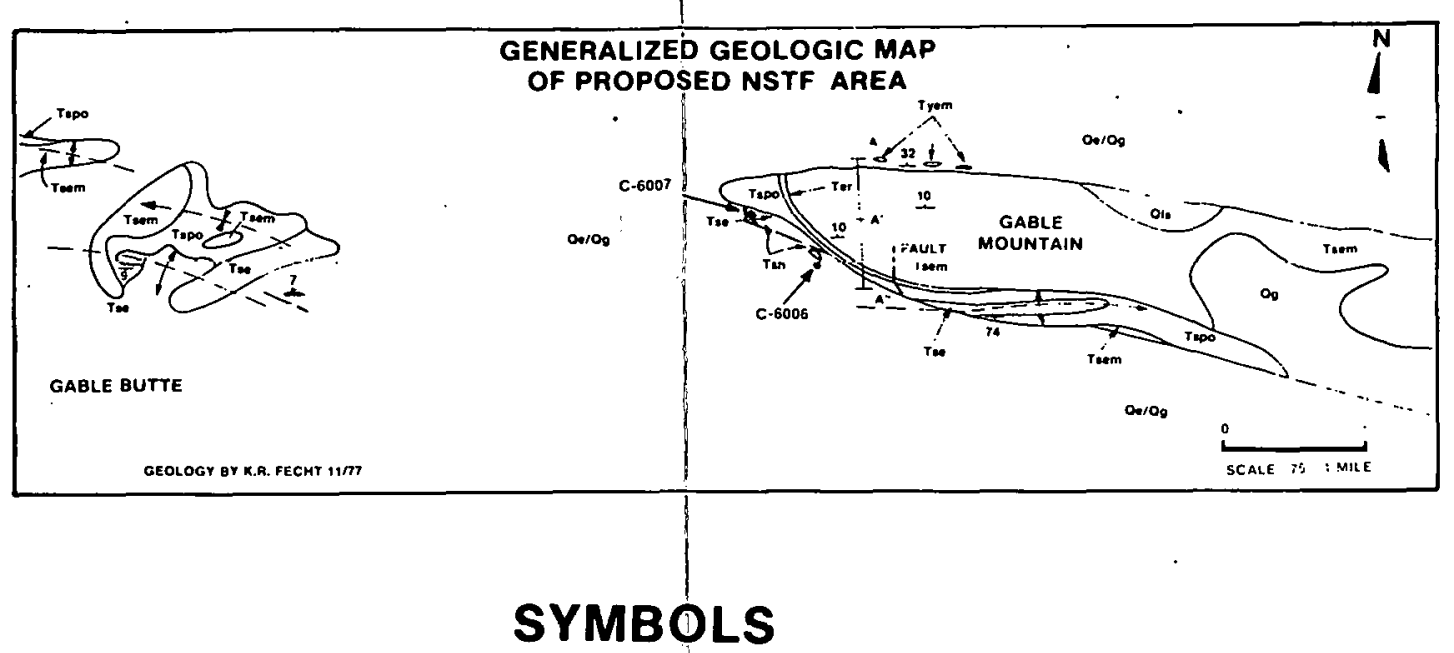

$77 f^{\text {Feow }}$ ENTablatuae

CGOO-SAMPLE POINT
ELEVATIN ABOVE
MEAN SEA LEYEL

? D

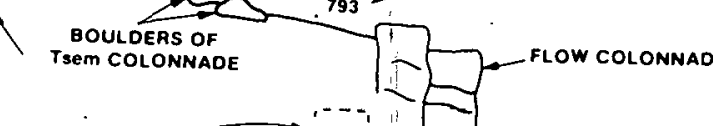

DASHEO.PPOJECTION
BELOW GROUND SURFACE

Qe/Og de UNIT MANTLES Qg UNIT

Trem-Qr. TSem UNIT PRESENT WITH Or. UNIT

CONTACT BETWEEN LITHOLOGES \& INTRAUNIT DISCONTINUTITIES

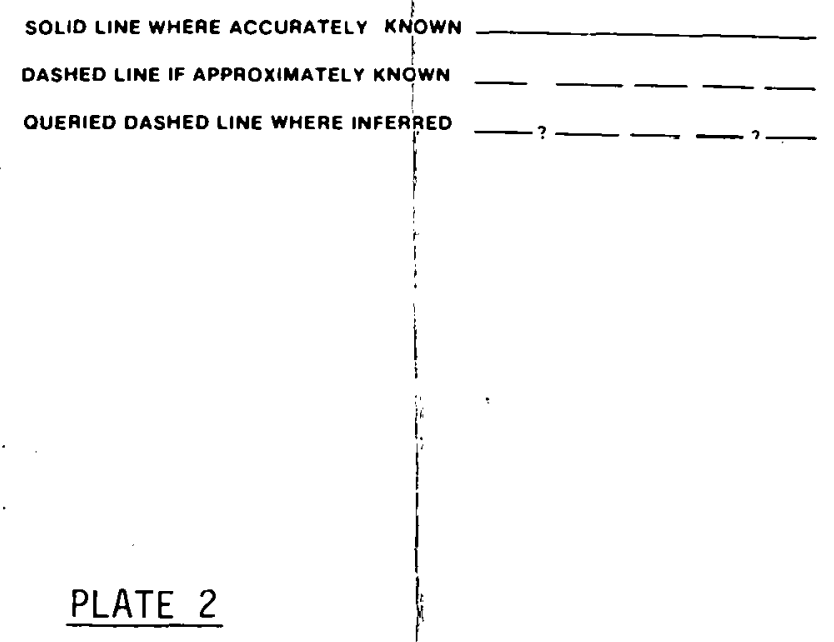

PLATE 2 